\title{
Molecular biology methods for blood cell antigen genotyping in reference laboratories
}

\author{
Katarzyna Guz ${ }^{1} \odot$, Agnieszka Orzińska ${ }^{1} \odot$, Bogumiła Michalewska ${ }^{1}$, \\ Monika Pelc-Kłopotowska ${ }^{1} \odot$, Ewa Brojer ${ }^{1} \odot$, Magdalena Łętowska ${ }^{2} \odot$ \\ ${ }^{1}$ Department of Immunohematology and Immunology for Transfusion Medicine; Institute of Hematology \\ and Transfusion Medicine in Warsaw \\ ${ }^{2}$ Department of Transfusion Medicine, Institute of Hematology and Transfusion Medicine in Warsaw
}

\begin{abstract}
Summary
The aim of the study is to present current applications of molecular biology methods in immunohematology as well as the status of their implementation in the Polish Blood Transfusion Service. Molecular biology methods are used for: analysis of molecular background of blood cell antigens in individuals with discrepant results of serological tests, identification of RhD antigen with weak expression undetectable by serological methods in blood donors, identification of weak $D$ type antigen in recipients unsusceptible to alloimmunization. These methods are also used for noninvasive study of fetal genes in plasma samples of immunized pregnant women with serological incompatibilities and in RhD negative pregnant women for qualification to antenatal prophylactic administration of anti-D immunoglobulin. Molecular biology is also an important tool for diagnostics of patients with antibodies to high-frequency blood group antigens (HFA) or for patients immunized with HPA and HNA antigens and for identification of "antigen-negative" blood donors for such patients. In Poland, all these tests are available and in use.
\end{abstract}

Key words: molecular methods for genotyping, blood group antigens, platelet antigens (HPA), granulocyte antigens (HNA), immunohematological studies

J. Transf. Med. 2019; 12: 199-205

\section{Introduction}

Molecular typing of blood cell antigens has been steadily developing since the first reports on DNA sequences of genes coding the clinically significant blood cell antigens which were published in 1989/1990. Since mid-1990s the methods were gradually introduced into the diagnostic process [1-4], initially for platelet and granulocyte antigen typing, where serological methods proved inadequate [4-8].

Since the beginning of 2000 , molecular biology methods have also been applied to red blood cell antigen typing, which was made possible due to successful studies of genetic background of blood group systems [9-11].
Current status of application of molecular biology methods in reference laboratories in Poland and worldwide

At present, both in Poland and worldwide, DNA-based methods are used mainly in highly specialized immunohematology reference laboratories [9-14].

Methods are based on the polymerase chain reaction (PCR). The earliest developed PCRbased assays rely on the amplification using sequence specific primers (PCR-SSP) and pattern analysis of the $\mathrm{PCR}$ products in agarose gel or on the electrophoretic analysis of restriction fragment length polymorphism (PCR-RFLP)

Adres do korespondencji: Katarzyna Guz PhD, Department of Immunohematology and Immunology for Transfusion Medicine, 00-791 Warszawa, ul. Chocimska 5, e-mail:kguz@ihit.waw.pl

Translation: mgr Krystyna Dudziak 
after digestion of PCR products with restriction enzymes matched to the alleles. A more recent modification of this technique is $\mathrm{PCR}$ based on fluorescent staining of the amplification product, i.e. real-time PCR with allele specific TaqMan or HybProbe probes or with SYBR Green DNA intercalating dyes. Real-time PCR methods based on the analysis of the amplification product melting curve (HRM) are also used (Table 1) [12-14]. The blood transfusion service in the Netherlands makes use of a technique based on Multiplex Ligation-dependent Probe Amplification (MLPA) [15]. A growing number of centers is beginning to make use of technologies designed for larger-scale research, including technologies based on microarrays, mass spectrometry, digital PCR. There is also ongoing research on next generation sequencing (NGS). The above issues have been described by the authors in separate papers published in 2019 [16, 17].

Genotyping studies are based on the so called home made tests or, if available, on standardized IVD marked (in vitro diagnostics) commercial tests. Table 2 presents a list of such tests which also appears in Guz et al. 2019 [16].

If above described methods give no equivocal answers with regard to molecular basis of the antigen, additional tests are necessary which are mainly based on sequencing the antigen-encoding gene. The classical Sanger method is usually used, but such analyses can also be performed with next-generation sequencing (NGS) [17].

The IVD commercial tests listed in Table 2 and used for consultation testing at the Institute of Hematology and Transfusion Medicine (IHTM) are "low throughput" tests for single-sample testing. On the other hand, developed at the IHTM real-time PCR home made tests with automated DNA isolation and automated preparation of the mixture of reagents for PCR have "average throughput" which depends on the size of the thermal block in real-time PCR thermocycler and usually analyzes 96-384 samples for one polymorphism at a time. Such tests require an automated DNA isolation device and a pipetting station.

Molecular biology tests currently performed at the IHTM reference laboratory are like those performed in immunohematology laboratories worldwide and focus on:

1. investigation of discrepancy between results of routine serological typing in immunohematology laboratories for determination of $\mathrm{ABO}$ and/or Rh group or for matching blood for transfusion;
Table 1. Low and medium throughput methods used for blood group genotyping in reference laboratories worldwide:

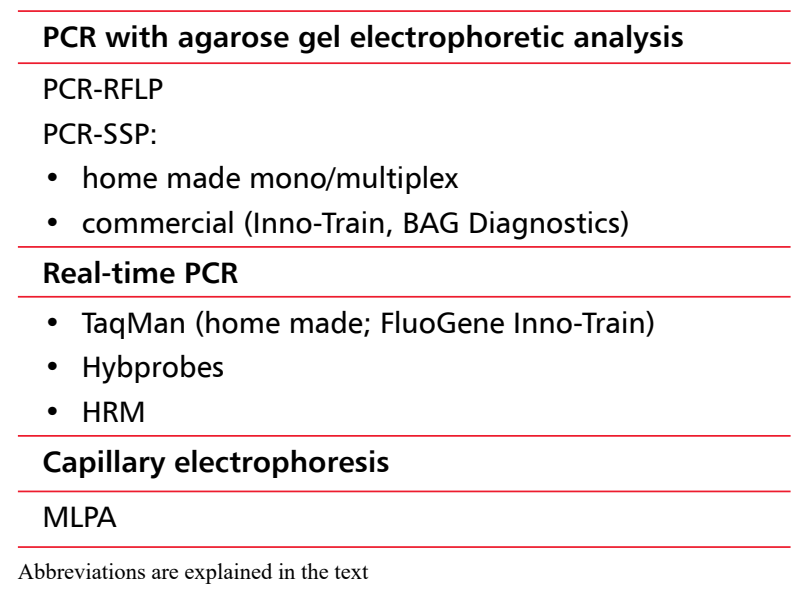

2. identification of donors with weak $\mathrm{RhD}$ antigen expression, undetectable by serological methods;

3. identification of serologically weak $\mathrm{D}$ type 1,2 or 3 antigens in recipients and pregnant women unsusceptible to anti-D alloimmunization;

4. non-invasive fetal blood antigen genotyping of women with feto-maternal incompatibility;

5. non-invasive fetal $\mathrm{RhD}$ typing in $\mathrm{RhD}$-negative women to qualify $\mathrm{RhD}$ positive fetus for antenatal anti-D immunoprophylaxis;

6. blood group antigen genotyping in search for „antigen negative” donors for patients with alloantibodies to the high-frequency antigens;

7. HPA and HNA antigen genotyping in diagnostics of cases suspected of alloimmunization and for establishing a registry of donors with typed HPA/HNA antigens for immunized patients.

We present below the application areas for molecular biology methods.

1. Investigation of discrepancies between results of routine serological typing, mainly difficulties in $\mathrm{ABO}$ and $\mathrm{Rh}$ typing, and matching blood for transfusion

A detailed list of application areas for molecular biology methods is presented in points 1, 2 and 3 of Table 3. Molecular biology tests are always preceded by serological tests performed at the IHTM reference laboratory. Based on the results of serological tests, the Laboratory of Blood Group Genetics decides on the choice of molecular biology technique using different tests detailed in Table 2. [18-20].

2. Identification of donors with weak $\mathrm{RhD}$ antigen expression undetectable by serological methods 
Table 2. Tests currently available for erythrocyte, platelet and granulocyte antigen genotyping at IHTM

Commercial IVD tests (PCR SSP: RBC Ready Gene with gel analysis or real-time PCR RBC FluoGene Inno-Train):

Erythrocytes: Rh (CDE, D weak/DEL, D neg), KKD (K/k, Jka/b, Fy $\left.{ }^{a / b}, F Y^{\text {null }}(-67 C), F Y^{\star} X\right), M N S(M / N, S / s, V w, M g), ~ R a r e$

$\left(\mathrm{Kp}^{\mathrm{a} / \mathrm{b}}, \mathrm{Lu}^{\mathrm{a} / \mathrm{b}}, \mathrm{Di}^{\mathrm{a} / \mathrm{b}}, \mathrm{Wr}^{\mathrm{a} / \mathrm{b}}, \mathrm{Yt}^{\mathrm{a} / \mathrm{b}}, \mathrm{Co}^{\mathrm{a} / \mathrm{b}}, \mathrm{Kn}^{\mathrm{a} / \mathrm{b}}, \mathrm{Do}^{\mathrm{a} / \mathrm{b}}\right), \mathrm{ABO}\left(\mathrm{O} 1, \mathrm{O} 2^{\prime}, \mathrm{A}, \mathrm{A} 2, \mathrm{~B}\right)$

Assessment of $R H D$ zygosity of Rh+ fathers in Rh incompatibility

HPA-1, 2, 3, 4, 5, 6, 9, 15

HNA-1, 3, 4, 5

Real-time PCR home made tests (TaqMan probes):

end point analysis: RhE/e, K/k, M/N, S/s, Jk ${ }^{a / b}, F^{a / b}, F Y^{n u l l}(-67 C), F Y^{*} X, K p^{a / b}, W r^{a / b}, D^{a / b}, K n^{a / b}, Y^{a / b}, C^{a / b}, L^{a / b}, L u 8 / 14$, Lwa/b, P1/P2, SC:1/2, Vel(-), LAN(-), Jra(-) oraz HPA-1,-2,-3,-5,-15 i HNA-3, 4, 5 :

- genotyping of patients, donors

- determination of fetal status from invasively collected material

Real-time analysis:

- non-invasive fetal RhD, RhC, Rhc, RhE, K, HPA-1a from maternal plasma

- identifying type 1, 2, 3 recipients with a weak D phenotype

- searching for $R H D+$ donors (D weak, DEL) among negative Rh donors

It is known from the literature that blood of serologically negative donors with weak $\mathrm{D}$ antigen expression may be immunogenic and induce the formation of immunogenic alloantibodies in the recipient $[21,22]$. The IHTM has developed a system of identifying such donors $[23,24]$ based on $R H D$ gene detection in DNA isolated from a plasma pool of serologically $\mathrm{RhD}$ negative donors. On $R H D$ gene detection further tests are performed in cross pools or individual samples to identify a donor with $R H D$. Subsequent molecular and serological typing determines whether $R H D$ gene expression occurs i.e. whether the $\mathrm{D}$ antigen can be detected by methods more sensitive than the routinely used, adsorption/elution in particular $[23,24]$. Detection in pooled plasma samples from many donors markedly reduces the cost of DNA isolation and identification of donors with immunogenic $\mathrm{D}$ antigen. The estimated cost is about PLN 50 per donor assuming that each pool consists of samples from $48 \mathrm{RhD}$ negative donors. Such tests are currently performed in several European countries (Germany, Austria, Switzerland), though the strategy in those countries consists in pooling DNA isolated from whole blood [25, 26]. According to literature, 30 antigen $\mathrm{D}$ molecules are sufficient to elicit the immune response in a recipient. It therefore follows that formation of anti-D antibodies in a patient may be induced by transfusion of red blood cell concentrate from a donor with weak antigen $\mathrm{D}$ expression. Alloimmunization may be induced even by transfusion from a donor with DEL type antigen which is detected only by adsorption/elution not routinely performed [22].
The IHTM program financed by the National Science Center (NCN) demonstrated that the potentially immunogenic $\mathrm{D}$ antigen is detected in approximately $0.09 \%$ of donors routinely typed as $\mathrm{D}$ negative. All identified donors were with $\mathrm{C}+$ and/or E + phenotypes [23]. For greater safety of $\mathrm{RhD}$ negative recipients, $\mathrm{RhD}$ negative $\mathrm{C}+$ and/ /or E + donors should be genetically tested, and donors with $R H D$ gene variant encoding $\mathrm{D}$ antigen expression should be qualified as $\mathrm{RhD}$ positive donors. Appropriate research methodology has been developed and the program is ready for implementation. The estimated cost of testing a plasma pool of 24 negative $\mathrm{Rh}$ donors with the $\mathrm{C}+$ or $\mathrm{E}+$ phenotype is estimated at approximately PLN 80 per donor.

3. Identification of weak $D$ type 1,2 or 3 antigen in recipients and pregnant women unsusceptible to alloimmunitzation

Implementation of molecular biology methods for analysis of the $R H D$ gene in patients with $\mathrm{RhD}$ antigen undetermined in serological tests, led to identification of $\mathrm{D}$ antigen variants $[12,13,27]$.

Long-term observations have demonstrated that individuals with weak D type 1, 2 or 3 antigens do not produce anti-D alloantibodies despite exposure to $\mathrm{RhD}$-positive blood (antigen incompatible fetus or transfused blood). If anti-D antibodies are detected, they are always autoantibodies [27]. Therefore, individuals with such weak D antigen variants may be transfused with red blood cells from positive $\mathrm{RhD}$ donors, and women do not require anti-D immunoglobulin after miscarriage or delivery of a RhD positive newborn. Antigen $\mathrm{D}$ 
Table 3. Molecular biology methods in immunohematology of blood groups

\begin{tabular}{|c|}
\hline $\begin{array}{l}\text { 1. Determination of phenotype: } \\
\text { - in patients after multiple transfusions: two red blood cell populations up to } 3 \text { months following transfusion } \\
\text { - when blood cells are coated with IgG autoantibodies (positive direct anti-globulin test - DAT) } \\
\text { - when suspected immunization with common or rare antigens } \\
\text { - when no diagnostic sera are available (e.g. anti-VS, -Ytb; }-\mathrm{Js}^{\mathrm{a}},-\mathrm{Vel},-\mathrm{Co}^{\mathrm{a}} \text { ) }\end{array}$ \\
\hline $\begin{array}{l}\text { 2. Assistance in the identification of immunogenic antibodies: } \\
\text { - determination of the presence/absence of the antigen corresponding to suspected specificity of antibodies in case of } \\
\text { ambiguous serological results } \\
\text { - help in distinguishing allo- from auto-antibodies by determining the patient's genotype/phenotype and indicating } \\
\text { phenotype of the reference red blood cells needed for alloadsorption }\end{array}$ \\
\hline $\begin{array}{l}\text { 3. Investigating the causes of discrepancies in serological typing - identifying variants: } \\
\text { - } R H D \text { gene with atypical expression of } D \text { : weak } D \text {, partial } D, D E L \text { in Rh negative individuals } \\
\text { - } R H C E \text { gene with atypical expression of } C / c \text { and/or E/e antigens } \\
\text { - } A B O \text { gene } \\
\text { - } A C K R 1 / D A R C \text { gene: FYnull }(-67 C) \text {, weak } \mathrm{Fy}^{\mathrm{b}}\left(F Y^{*} X\right)\end{array}$ \\
\hline $\begin{array}{l}\text { 4. Non-invasive fetal blood group/HPA genotyping from maternal blood: } \\
\text { - in immunized pregnant women with alloantibodies (anti-D, }-C,-G,-C,-E,-K,-H P A-1 a) \\
\text { - in non-immunized RhD negative women for qualification to antenatal anti-D prophylaxix }\end{array}$ \\
\hline 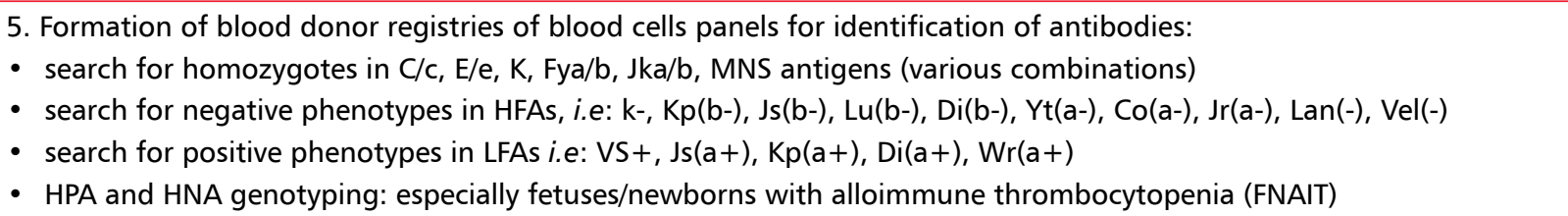 \\
\hline
\end{tabular}

alloimmunization has been described in individuals with other weak $\mathrm{D}$ antigen variants, such as weak D type 4.2 (DAR), 11 and 15 [27, 28].

The IHTM methodology for genotyping antigen $\mathrm{D}$ variants in individuals with discrepant or weak positive results of serological typing enabled the assessment of the frequency of weak or partial D antigen variants in Poland. The 2019 data of 693 individuals with inconclusive results demonstrated that alleles responsible for weak antigen D type 1 , 2,3 were detected in $79 \%$ and in the remaining $21 \%$ alleles susceptible to immunization with antigen $\mathrm{D}$ were identified (defining weak D, partial D or DEL antigen) [29].

Previous estimates of blood donors only have revealed that routine serological antigen $\mathrm{D}$ typing is unequivocal in $0.2 \%(20 / 10000)$ and most of them $(14 / 10000)$ were also genetically defined as $R H D^{*} 01 W .1, R H D * 01 W .2 ; R H D * 01 W .3$, i.e. unsusceptible to alloimmunization [30].

4. Non-invasive fetal genotyping of women with feto-maternal incompatibility

The IHTM developed and implemented non-invasive fetal typing of RHD and RHCE genes in women with feto-maternal incompatibility for $\mathrm{D}$, $\mathrm{C}, \mathrm{c}$ and $\mathrm{E}$ antigens. IHTM performs prenatal diagnostics for immunized women with anti-D $(+\mathrm{C})$, anti-c, anti -E or anti-G antibodies from all over the country. Standardization studies demonstrated a $100 \%$ compliance of the newborn phenotype/ /genotype with fetal DNA genotype from maternal plasma. Ongoing are standardization studies on $K E L * 1$ allele in plasma of pregnant women with anti-K alloantibodies [31-36].

5. Non-invasive fetal $R H D$ genotyping of RhD negative pregnant women for qualification to antenatal anti-D prophylaxis

Several Western European countries have implemented routine non-invasive fetal $R H D$ genotyping in maternal plasma of $\mathrm{RhD}$ negative pregnant women as criteria for antenatal anti-D prophylaxis for those with $R H D$ positive fetus [37-40]. The program generated $40 \%$ savings of anti-D immunoglobulin which counterbalanced the cost of program implementation. It is worth emphasizing that due to the screening program women carrying a RHD negative fetus are not exposed to unnecessary administration of anti-RhD immunoglobulin, which is produced from plasma of blood donors immunized with $\mathrm{RhD}$ positive red blood cells. The IHTM has developed a system for large-scale screening [41, 42]. Automation of the process of DNA isolation from plasma and preparation of PCR reactions for fetal $R H D$ 
detection allows to perform testing of all Polish $\mathrm{RhD}$ negative women in as few as one or two centers, providing logistics of sample delivery is effective.

6. Genotyping of blood group antigens in search for, high-frequency antigen negative' donors for immunized patients

Alloimmunization against antigens which are present with the high frequency in the general population (HFA "high-frequency antigens") is a challenge for transfusion medicine since it is difficult to identify the right donor (with no antigen) for a patient who requires transfusion $[43,44]$. Finding the HFA negative blood donor often involves screening of several hundred or even thousand blood donors with serological methods which often prove inadequate due to the lack of diagnostic sera. The staff of the Laboratory of Red Blood Cell Immunology at IHTM is often confronted with such situations while performing consulting tests to identify antibodies to HFAs [45, 46]. At present, the major challenge for Polish blood transfusion service and IHTM is the implementation of molecular biology methods for i.e. low-frequency blood group antigens typing (LFA, the less frequent antithetic variants of HFAs), in order to identify donors with no HFAs.

The IHTM has presented the outcome of 17year studies on testing antibodies to HFAs. This data illustrates what i.e. rare blood group donors should be at the disposal of blood transfusion centers in order to provide safe transfusions for immunized patients, pregnant women and their fetuses/newborns [46]. The types of rare blood donors are listed in the Ministry of Health Regulation of 06.02.2017 (Journal of Laws 2017.235).

As a part of the research funded by the IHTM, methodology based on real-time PCR was developed for identifying donors compatible with patients with anti-Rh51(MAR)-like antibodies. Genetic typing is the only method of determining homozygous $C^{w} / C^{w}$ genotype in $\mathrm{C}+/ \mathrm{Cw}+$ individuals [47]. The register of $7 C^{w} / C^{w}$ donors identified at that time required expansion and in 2019 the IHTM was once more in search for such donors for a different patient (4 new donors were identified).

The IHTM has also developed low-cost screening tests for genotyping the most frequent mutations responsible for lack of expression of common HFAs such as: $\mathrm{Yt}^{\mathrm{a}}, \mathrm{Kp}^{\mathrm{b}}, \mathrm{Di}^{\mathrm{b}}, \mathrm{Co}^{\mathrm{a}}, \mathrm{Lu}^{\mathrm{b}}$, $\mathrm{Kn}^{\mathrm{a}}$, Lw ${ }^{\mathrm{a}}$, Vel, LAN [48]. A total of 948 donors were examined with the outcome of 6 donors with no $\mathrm{Yt}^{\mathrm{a}}$ antigen and one LAN negative donor. Currently, studies have been expanded to include genotyping of antigens: Lu8/14, SC1/2, Jr ${ }^{\mathrm{a}}$ (2 most common mutations), LAN (subsequent mutations), P1/P2. It should be stressed that the latter antigen typing is not possible with the commercially available tests since none of these have the reagants for their identificastion.

The IHTM sees the necessity of establishing a National Registry of Rare Blood Group Donors operated within the currently developing e-blood system which is created in order to support the Polish Blood Transfusion Service. Conversion of data into digital (i.e. computer-readable) format will facilitate supervision over the register resources, ensure permanent access to rare blood group components (management of collection schedule, stocks of frozen components) and render the registry resources open to foreign registers.

7. Establishment of a registry of HPA and HNA typed donors for immunized patients

Molecular biology methods are the leading methods for HPA and HNA typing of patients suspected of alloimmunization as well as of blood donors; no commmercial tests for phenotyping of these antigens are available (with the exception of HPA-1a antigen). Of particular importance is the establishment of registries of donors with typed HPA for diagnostic and transfusion purposes (Table 3 ) $[7,8,49-52]$.

The IHTM has published a list of accessible HPA and/or HLA typed donors of platelet concentrates (PCs) together with the methods used for their identification [52] and points to the necessity of establishing a National Registry of Donors with marked HPA operated also by the e-blood system. The registry should be expanded to include more HPA- $1 \mathrm{a}$ and HPA-5b negative donors due to the growing demand for this phenotype PCs dedicated primarily for fetal and neonatal transfusions in cases with recognized/suspected fetal/neonatal alloimmune thrombocytopenia (FNAIT) as result of feto-maternal incompatibility [53-56]. Donor-recipient genotype matching with regard to $\mathrm{PCs}$ may also apply to other HPA antigens, depending on the specificity of the anti-HPA antibodies. It may additionally require matching in HLA class I antigens [57].

As regards HNA antigens, the literature reports raise the need for HNA-3b/b genotype determination. Such donors should be tested for anti-HNA-3a antibodies, because they are the most common cause of Transfusion-Related Acute Lung 
Injury (TRALI), induced by immunization with HNA antigens. It is even postulated that donors with anti-HNA-3a antibodies should be deferred from donating blood for clinical use [58, 59].

In summary, molecular biology methods are used in the IHTM reference laboratory for every-day consultations under subsidy for the activities of the public blood transfusion service (Article 25 of the Act on public blood transfusion service of 22 August 1997). The laboratory also depends on its own funds and grants for implementation and recommendation of methods that strengthen the safety of blood transfusion

\section{References}

1. Yamamoto F, Marken J, Tsuji T, et al. Cloning and characterization of DNA complementary to human UDP-GalNAc: Fuc alpha 1-2Gal alpha 1-3GalNAc transferase (histo-blood group A transferase) mRNA. J Biol Chem. 1990; 265(2): 1146-1151, indexed in Pubmed: 2104828.

2. Daniels G. Human Blood Groups, 3rd Edition. Wiley-Blackwell 2013.

3. Reid ME, Lomas-Francis C, Olsson M. The blood group antigen. 3rd Edition. Elsevier Ltd London, UK 2012.

4. Newman PJ, Derbes RS, Aster RH. The human platelet alloantigens, PIA1 and PIA2, are associated with a leucine33/proline33 amino acid polymorphism in membrane glycoprotein IIIa, and are distinguishable by DNA typing. J Clin Invest. 1989; 83(5): 1778-1781, doi: 10.1172/JCI114082, indexed in Pubmed: 2565345.

5. Huizinga TW, Kleijer M, Tetteroo PA, et al. Biallelic neutrophil Na-antigen system is associated with a polymorphism on the phospho-inositol-linked Fc gamma receptor III (CD16). Blood. 1990; 75(1): 213-217, indexed in Pubmed: 2136803.

6. Brojer E, Uhrynowska M, Drzewek K, et al. Serologiczna i genetyczna analiza częstości antygenów NA ludzkich granulocytów. Acta Haematol Pol. 1997; 28: 155-162.

7. Drzewek K, Brojer E, Zupańska B. The frequency of human platelet antigen (HPA) genotypes in the Polish population. Transfus Med. 1998; 8(4): 339-342, doi: 10.1046/j.13653148.1998.00164.x, indexed in Pubmed: 9881429.

8. Guz K, Brojer E, Zupańska B. Implications of NA1/NA2 and SH genotyping results in the Polish population with regard to the new nomenclature of granulocyte alloantigens. Transfusion. 2000; 40(4): 490-491; author reply 492, doi: 10.1046/j.15372995.2000.40040490.x, indexed in Pubmed: 10773063.

9. Guz K, Orzińska A, Brojer E. Przegląd metod genotypowania antygenów krwinek czerwonych. J Transfus Med. 2013; 6: 90-95.

10. Orzińska A, Guz K, Brojer E. Nowe osiagnięcia w badaniach nad podstawami molekularnymi grup krwi. J Transfus Med. 2013; 6: 101-104.

11. Westhoff CM. Molecular DNA-based testing for blood group antigens: recipient-donor focus. ISBT Science Series. 2013; 8(1): 1-5, doi: 10.1111/voxs.12049.

12. Peyrard T. Use of genomics for decision-making in transfusion medicine: laboratory practice. ISBT Science Series. 2013; 8(1): 11-15, doi: 10.1111/voxs.12002.

13. Svensson A, Delaney M. Considerations of red blood cell molecular testing in transfusion medicine. Expert Rev Mol Diagn. 2015; 15: 1455-1464.
14. Reid ME, Denomme GA. DNA-based methods in the immunohematology reference laboratory. Transfus Apher Sci. 2011; 44(1): 65-72, doi: 10.1016/j.transci.2010.12.011, indexed in Pubmed: 21257350 .

15. Haer-Wigman L, Ji Y, Lodén M, et al. Comprehensive genotyping for 18 blood group systems using a multiplex ligation-dependent probe amplification assay shows a high degree of accuracy. Transfusion. 2013; 53(11 Suppl 2): 2899-2909, doi: 10.1111/trf.12410, indexed in Pubmed: 23992446.

16. Guz K, Orzińska A, Brojer E. Rozwój technologii opartych na metodach biologii molekularnej do oznaczania grup krwi. J Transf Med. 2019; 12(2): 56-64, doi: 10.5603/jtm.2019.0002.

17. Orzinska A, Guz K, Brojer E. Potential of next-generation sequencing to match blood group antigens for transfusion. Intern J Clin Trans Med. 2019; Volume 7: 11-22, doi: 10.2147/ijctm. s175142.

18. Michalewska B, Żupańska B, Pelc-Kłopotowska M, et al. Alloimmunizacja u chorych na niedokrwistość auto-immunohemolityczną oraz genotypowanie krwinek czerwonych w celu udoskonalenia doboru krwi do przetoczeń. J Transfus Med. 2009; 2: 14-19.

19. Olsson ML, Michalewska B, Hellberg A, et al. A clue to the basis of allelic enhancement: occurrence of the Ax subgroup in the offspring of blood group O parents. Transfus Med. 2005; 15(5): 435-442, doi: 10.1111/j.1365-3148.2005.00603.x, indexed in Pubmed: 16202060.

20. Polin H, Pelc-Klopotowska M, Danzer M, et al. Compound heterozygosity of two novel RHAG alleles leads to a considerable disruption of the Rh complex. Transfusion. 2016; 56(4): 950-955, doi: 10.1111/trf.13476, indexed in Pubmed: 27079312.

21. Mota M, Fonseca NL, Rodrigues A, et al. Anti-D alloimmunization by weak $\mathrm{D}$ type 1 red blood cells with a very low antigen density. Vox Sang. 2005; 88: 130-135.

22. St-Louis M, Lebrun A, Goldman M, et al. Alloimmunization of patients by blood units harboring distinct DEL variants. Immunohematology. 2013; 29(4): 136-140, indexed in Pubmed: 24689683.

23. Orzińska A, Guz K, Polin H, et al. RHD variants in Polish blood donors routinely typed as D-. Transfusion. 2013; 53(11 Suppl 2): 2945-2953, doi: 10.1111/trf.12230, indexed in Pubmed: 23634715 .

24. Pelc-Kłopotowska M, Orzińska A, Michalewska B, et al. Badanie obecności fragmentów genu RHD u dawców RhD ujemnych z zastosowaniem minipulowania i technologii real-time PCR. J Transf Med. 2008; 1: 40-45.

25. Flegel WA, Wagner FF, Müller TH, et al. Rh phenotype prediction by DNA typing and its application to practice. Transfus Med. 1998; 8(4): 281-302, doi: 10.1046/j.1365-3148.1998.00173.x, indexed in Pubmed: 9881423.

26. Crottet SL, Henny C, Meyer S, et al. Implementation of a mandatory donor RHD screening in Switzerland. Transfus Apher Sci. 2014; 50(2): 169-174, doi: 10.1016/j.transci.2014.02.011, indexed in Pubmed: 24679597.

27. Sandler SG, Chen LN, Flegel WA. Serological weak D phenotypes: a review and guidance for interpreting the $\mathrm{RhD}$ blood type using the RHD genotype. Br J Haematol. 2017; 179(1): 10-19, doi: 10.1111/bjh.14757, indexed in Pubmed: 28508413.

28. Pham BN, Roussel M, Gien D, et al. Molecular analysis of patients with weak $\mathrm{D}$ and serologic analysis of those with anti-D (excluding type 1 and type 2). Immunohematology. 2013; 29(2): 55-62, indexed in Pubmed: 24094237. 
29. Pelc-Kłopotowska M, Guz K, Orzińska A, et al. Evaluation of reactivity of various monoclonal anti-D reagents with red blood cells of individuals with inconclusive RHD variants. XXVIII PTHiT, Łodź 12-14.09. 2019, Zeszyt Streszczeń.: 58-59.

30. Pelc-Kłopotowska M, Guz K, Wróbel J, et al. Charakterystyka molekularna i serologiczna słabych odmian antygenu $\mathrm{D}$ u dawców RCKiK w Białymstoku. Acta Haematologica Polonica. 2015; 46: 123, doi: 10.1016/j.achaem.2015.07.245.

31. Orzińska A, Guz K, Brojer E, et al. Badanie genu RHD płodu w osoczu zimmunizowanej matki Rh ujemnej pozwoliło na uniknięcie metod inwazyjnych i urodzenie zdrowego dziecka. Gin Pol. 2004; 75; 12: 963-965.

32. Guz K, Brojer E, Żupańska B, et al. Nieinwazyjna diagnostyka RHD płodu u RhD ujemnych kobiet ciężarnych - wyniki wstępne. Gin Pol. 2004; 75: 21-25.

33. Brojer E, Zupanska B, Guz K, et al. Noninvasive determination of fetal RHD status by examination of cell-free DNA in maternal plasma. Transfusion. 2005; 45(9): 1473-1480, doi: 10.1111/j.15372995.2005.00559.x, indexed in Pubmed: 16131380.

34. Orzińska A, Guz K, Brojer E, et al. Preliminary results of fetal Rhc examination in plasma of pregnant women with anti-c. Prenat Diagn. 2008; 28(4): 335-337, doi: 10.1002/pd.1977, indexed in Pubmed: 18382999.

35. Orzińska A, Guz K, Gala K, et al. The influence of methods of maternal collection and storage and DNA isolation on detection of fetal genes in maternal plasma in noninvasive prenatal diagnostics. Diagn Lab. 2007; 43: 69-77.

36. Orzińska A, Guz K, Dębska M, et al. 14 Years of Polish Experience in Non-Invasive Prenatal Blood Group Diagnosis. Transfus Med Hemother. 2015; 42(6): 361-364, doi: 10.1159/000440821, indexed in Pubmed: 26733766.

37. Clausen FB, Steffensen R, Christiansen M, et al. Routine noninvasive prenatal screening for fetal RHD in plasma of RhD-negative pregnant women-2 years of screening experience from Denmark. Prenat Diagn. 2014; 34(10): 1000-1005, doi: 10.1002/ pd.4419, indexed in Pubmed: 24860987.

38. Thurik FF, Ait Soussan A, Bossers B, et al. Analysis of false-positive results of fetal RHD typing in a national screening program reveals vanishing twins as potential cause for discrepancy. Prenat Diagn. 2015; 35(8): 754-760, doi: 10.1002/pd.4600, indexed in Pubmed: 25855535.

39. Szczepura A, Osipenko L, Freeman K. A new fetal RHD genotyping test: costs and benefits of mass testing to target antenatal anti-D prophylaxis in England and Wales. BMC Pregnancy Childbirth. 2011; 11: 5, doi: 10.1186/1471-2393-11-5, indexed in Pubmed: 21244652.

40. Tiblad E, Taune Wikman A, Ajne G, et al. Targeted routine antenatal anti-D prophylaxis in the prevention of $\mathrm{RhD}$ immunisation-outcome of a new antenatal screening and prevention program. PLoS One. 2013; 8(8): e70984, doi: 10.1371/journal. pone.0070984, indexed in Pubmed: 23940682.

41. Orzińska A, Guz K, Purchla-Szepioła S, et al. 2-year experience in non-invasive prenatal diagnostics of fetal rhd for targeted anti-d immunoprophylaxis in Poland. Vox Sanguinis. 2018; 113(Suppl. 1): 276.

42. Orzińska A, Guz K, et al. Purchla-Szepioła 3-lata nieinwazyjnej diagnostyki RHD płodu dla celowanej śródciążowej immunoprofilaktyki anty-D. XXVIII PTHiT, Łodź 12-14.09. 2019, Zeszyt Streszczeń 95-96.

43. Michalewska B. Częstość niezgodnych prób krzyżowych przy braku alloprzeciwcial wykrywanych w badaniach przeglądowych. Acta Haemat Pol. 2002; 33: 205-212.
44. Michalewska B, Pelc-Kłopotowska M, Łopieńska H, et al. Ocena $\mathrm{w}$ teście erytrofagocytozy klinicznego znaczenia rzadko wykrywanych alloprzeciwciał czerwonokrwinkowych. Acta Haemat Pol. 2006; 37: 407-414.

45. Łopieńska H, Michalik M, Ożóg A, et al. Alloprzeciwciała do antygenów występujących $\mathrm{z}$ wysoką częstością wykryte w Polsce w latach 2000-2012. Acta Haematologica Polonica. 2013; 44: 120, doi: 10.1016/j.achaem.2013.07.108.

46. Pelc-Kłopotowska M, Guz K, Orzińska A, et al. Antibodies against high frequency antygen in Polish patients between 2000 and 2017. Vox Sang. 2018; 113(Supp. 1): 227.

47. Orzińska A, Guz K, Michalewska B, et al. Molecular screening of the $\mathrm{C}$ antigen for typing donors compatible with patients with anti-MAR-like antibodies. Blood Transfus. 2016; 14(6): 573-576, doi: 10.2450/2015.0044-15, indexed in Pubmed: 26509828.

48. Guz K, Orzińska A, Pelc-Kłopotowska M, et al. Identification of blood donors with rare red blood cell phenotypes using low-cost protocols. Vox Sang. 2018; 113(Suppl. 1): 263.

49. Li RS, Qiao ZL, Ling B, et al. Establishment of reference panel for human platelet antigen genotyping. Vox Sang. 2014; 107(2): 166-170, doi: 10.1111/vox.12149, indexed in Pubmed: 24697294.

50. Merzoni J, Fagundes IS, Lunardi LW, et al. Human platelet antigen genotyping of platelet donors in southern Brazil. Int J Immunogenet. 2015; 42(5): 329-335, doi: 10.1111/iji.12220, indexed in Pubmed: 26211915.

51. Maślanka K, Guz K, Uhrynowska M, et al. Rejestr dawców z oznaczonymi swoistymi antygenami płytek krwi (HPA) i jego zastosowanie w transfuzjologii. Acta Haematol Pol. 2005; 36: 189-196.

52. Guz K, Łopacz P, Gierszon A, et al. Ocena dostępności dawców koncentratów płytkowych o oznaczonych antygenach leukocytarnych i płytkowych dla pacjentów z przeciwciałami anty-HLA i/lub anty-HPA. J Transfus Med. 2019; 12(1): 1-12.

53. Lucas GF, Bendukidize N. HPA-1a(-), 5b(-) platelets for use in neonatal alloimmune thrombocytopenia--from ,Cinderella' product to standard component. Transfus Med. 2014; 24(2): 127-129, doi: 10.1111/tme.12108, indexed in Pubmed: 24684573.

54. Bertrand G, Kaplan C. How do we treat fetal and neonatal alloimmune thrombocytopenia? Transfusion. 2014; 54(7): 1698-1703, doi: 10.1111/trf.12671, indexed in Pubmed: 24773309.

55. Uhrynowska ME, Dębska M, Guz K, et al. [PREVFNAIT prevention of foetal/neonatal alloimmune thrombocytopenia (FNAIT) in Polish foetuses and newborns--the PREVFNAIT program]. Ginekol Pol. 2015; 86(1): 62-66, doi: 10.17772/gp/1901, indexed in Pubmed: 25775877.

56. Brojer E, Husebekk A, Dębska M, et al. Fetal/Neonatal Alloimmune Thrombocytopenia: Pathogenesis, Diagnostics and Prevention. Arch Immunol Ther Exp (Warsz). 2016; 64(4): 279-290, doi: 10.1007/s00005-015-0371-9, indexed in Pubmed: 26564154.

57. Weinstock C, Schnaidt M. Human Leucocyte Antigen Sensitisation and Its Impact on Transfusion Practice. Transfus Med Hemother. 2019; 46(5): 356-369, doi: 10.1159/000502158, indexed in Pubmed: 31832061.

58. Storch EK, Hillyer CD, Shaz BH. Spotlight on pathogenesis of TRALI: HNA-3a (CTL2) antibodies. Blood. 2014; 124(12): 1868-1872, doi: 10.1182/blood-2014-05-538181, indexed in Pubmed: 25006121.

59. Bougie DW, Peterson JA, Kanack AJ, et al. Transfusion-related acute lung injury-associated HNA-3a antibodies recognize complex determinants on choline transporter-like protein 2 . Transfusion. 2014; 54(12): 3208-3215, doi: 10.1111/trf.12717, indexed in Pubmed: 24846273. 